\title{
THE IMPACT OF COVID 19 ON HIGHER EDUCATION AND WAY FORWARD: THE BANGLADESH PERSPECTIVE
}

\author{
Khadiza Rahman Tanchi, Farhana Noor and Shah-Noor Rahman \\ Assistant Professor, Department of Business Administration, \\ Daffodil International University, Dhaka, Bangladesh \\ Md Kamruzzaman \\ Assistant Professor, Department of Innovation \& Entrepreneurship, \\ Daffodil International University, Dhaka, Bangladesh

\section{Gouranga Chandra Debnath} \\ Associate Professor, Department of Business Administration, \\ Daffodil International University, Dhaka, Bangladesh
}

\begin{abstract}
An online survey was conducted to assess the impact of COVID-19 on higher education of public and private universities of Bangladesh and the time frame of data collection was from August 25 to September 10, 2020. To collect data a structured questionnaire link was used and 'Google form' was sent to respondents through email, Facebook messenger, WhatsApp. A total of 434 respondents participated and in this survey. To measure the impact of COVID-19 on higher education, a simple percentage distribution and descriptive statistics used. It's found from the analysis that almost $70 \%$ of learners were involved in e-learning during this pandemic situation. In this pandemic situation students have been facing various problems such as anxiety, depression, low quality internet connectivity, uncomfortable study environment at home. Students especially from distant areas and demoted sections face huge problems regarding study in this pandemic. This study has suggested some recommendations to the authorities of educational institutions, to the government and policymakers for betterment of students. Immediately some strategies are needed to build a strong and steady education system which will ensure to develop skills for employability and productivity in the mind of young generations.
\end{abstract}

Key words: COVID-19, Online Learning, Higher Education 
Cite this Article: Khadiza Rahman Tanchi, Md Kamruzzaman, Farhana Noor, Shah-Noor Rahman and Gouranga Chandra Debnath, The Impact of COVID 19 on Higher Education and Way Forward: The Bangladesh Perspective, International Journal of Management, 11(12), 2020, pp.1763 -1772.

http://iaeme.com/Home/issue/IJM?Volume=11\&Issue $=12$

\section{INTRODUCTION}

The COVID-19 pandemic has had a major effect on people's lives and lifestyles since its first outbreak in china between late 2019 and early 2020. The most impacted viruses of the country are facing an ongoing health crisis and the consequences of which will long influence their economic and social system. The need to preserve social distance and to avoid the spread of the infection has resulted in a change in the distribution and delivery of a wide range of services. Such examples include the growing use of home delivery systems, the move to online lessons and remote work solutions (Favale et al, 2020). Coronavirus disease (COVID-19) first appeared in Wuhan city of China at the end of last year of 2019. On 11 March 2020, the rapid spread of COVID-19 has prompted the World Health Organization (WHO) to label it a 'pandemic' WHO, 2020; Pelmin, 2020). Gonzalez et al. (2000) mentioned in their study that about 600 million learners worldwide are affected provided the majority of government all over the world have set a mutual goal decreasing the extent of highly contagious disease by executing by executing lockdowns, societal distances; not engaging face to face teaching and migration restriction.

As stated by UNSECO as of 1 June 2020, 1, 2 billion learners worldwide (68.0 per cent of the total enrolled learners worldwide) were affected by the closure of the academic organization in 144 countries, whereas all the academic institutes have stayed closed in Bangladesh since 17 March. More than 40 million students have lost their link to their regular education, and due to the financial crisis, a large number of these students may never return to school again. The reduction of school hours, however, is not the only effect of the Covid19 crisis. In addition to schooling, schools are also a critical source of social services, education, wellbeing and psychosocial help for children and young adults. Consequently, in addition to learning losses, school closures have far reaching effects on social and economic problems such as school dropouts, digital divide. A wider and deeper consequence of the Covid-19 education pandemic may emerge from the economic downturns caused by the pandemic control measures. SANEM (South Asian Network on Economic Modeling) estimates based on the latest Household Expenditure Survey (HIES) indicate that $23.90 \%$ (or 8.4 million) of the students' families were below the poverty line before the crisis. As the crisis prolongs, assuming a three-month lockout after 25 March and thus a 25.0 percent decrease in annual per capita income, SANEM estimates that as many as 43.90 percent of the families of the students could fall below the poverty line (primary: 51.70 percent, secondary: 42.40 percent; SSC / HSC: 30.20 percent; and university: 19.0 percent). Therefore, in this crisis, there could be as many as 7.70 million new student families dropping below the poverty line, bringing the total number of students below the poverty line to 16 million (Financial Express, 2020). School facility closures due to the outbreak COVID-19 have profound implications for education. According to the study of Abidah, Hidaayatullaah, Simamora, Fehabutar, \& Mutakinati (2020), it is found that through online learning teachers are instructed to teach during the lockdown. To overcome the mental stress and anxiety during the lockdown it is important to continue education through adopting innovative teaching techniques (Raju, 2020). (Strielkowski \& Kumar (2020) identified that due to the eruption of COVID 19 the digital revolution has occurred in higher education through different platforms such as online class or lectures, teleconferencing, online exams, open book exam and interaction through different virtual groups. Manzoor, (2020) mentioned that often 
the online mode of the teaching learning process discriminates against disadvantaged and oppressed students. It is understood that students with hearing impairments face difficulties in online learning. The present study objective is to identify the teaching learning status, learning methods and challenges related with study throughout this lockdown within COVID-19 pandemic.

\section{DATA AND METHODS}

This study is completely online survey-based report of 434 higher education including graduate and undergraduate students who studying in various public and private universities of Bangladesh.

\subsection{Collection and procedures}

From August 25 to September 10, 2020, information was collected to conduct the online survey. To collect information a structured questionnaire was sent to the students as 'Google Form' through their email, messenger, WhatsApp. This research adapted the questionnaire designed by Kapasia et al. (2020). Before conducting the survey it was confirmed that participants are fully agreed to the online survey and a total of 434 students provided information regarding the survey.

\subsection{Data Analysis}

To understand the study descriptive statistics were carried out for data analysis. Statistical Package for Social Science (SPSS Version: 22) was used to analyze the learning stance, mode of learning, thoughts and attitudes about educational problems and decision during this pandemic.

\section{RESULTS AND DISCUSSION}

\subsection{Participant's characteristics}

Table 1 Characteristics of the study participants

\begin{tabular}{|c|c|c|c|}
\hline Characteristics & Variables & $\begin{array}{l}\text { Frequency } \\
\text { (n) }\end{array}$ & $\begin{array}{l}\text { Percentage } \\
\quad(\%)\end{array}$ \\
\hline \multirow[t]{2}{*}{ What is your gender? } & Male & 266 & $61.3 \%$ \\
\hline & Female & 168 & $38.7 \%$ \\
\hline \multirow[t]{4}{*}{ What age group do you belong to? } & $18-20$ years & 110 & $25.3 \%$ \\
\hline & $21-23$ years & 246 & $56.7 \%$ \\
\hline & $24-26$ years & 64 & $14.7 \%$ \\
\hline & Above 26 years & 14 & $3.2 \%$ \\
\hline \multirow{2}{*}{$\begin{array}{l}\text { Is your institution/university a private } \\
\text { or public one? }\end{array}$} & Public & 72 & $16.6 \%$ \\
\hline & Private & 362 & $83.4 \%$ \\
\hline \multirow{2}{*}{$\begin{array}{c}\text { Are you an undergraduate or a } \\
\text { postgraduate student? }\end{array}$} & Postgraduate & 356 & $82.0 \%$ \\
\hline & Undergraduate & 78 & $18.0 \%$ \\
\hline \multirow[t]{4}{*}{ Monthly income of the family } & Below 30,000 & 134 & $30.9 \%$ \\
\hline & $30,000-50,000$ & 166 & $38.2 \%$ \\
\hline & $50,000-80,000$ & 84 & $19.4 \%$ \\
\hline & Above 80,000 & 50 & $11.5 \%$ \\
\hline \multirow[t]{3}{*}{ What is your subject or discipline? } & $\begin{array}{c}\text { Business (BBA, Marketing, Finance, } \\
\text { Accounting, MIS, HR, etc.) }\end{array}$ & 352 & $81.1 \%$ \\
\hline & $\begin{array}{c}\text { Science (CSE, software, Textile, EEE, } \\
\text { Pharmacy, Engineering, etc.) }\end{array}$ & 62 & $14.3 \%$ \\
\hline & Arts (English, JMC, Law, etc.) & 20 & $4.6 \%$ \\
\hline
\end{tabular}


Table 1 shows the demographic characteristics of the respondent of this study. From 434 students near to two thirds of them were male and rest of them were female. The highest number of students are from the age group of 21 to 23 years $(56.7 \%)$ followed by $18-20$ years $(25.3 \%)$. The majority of the students were from private universities $(83.4 \%)$ and undergraduate students (82.0\%), with business discipline almost (81.1\%). The monthly income shows that $38.2 \%$ student's family income range was from TK 30,000 to 50,000 followed by $30.9 \%$ student's family income range was below 30,000.

Table 2 Students doing online classes form Different divisions.

\begin{tabular}{|c|c|c|c|}
\hline Characteristics & Division & Frequency (n) & Percentage (\%) \\
\hline \multirow[t]{8}{*}{ From which division you are joining online classes? } & Dhaka & 240 & $55.3 \%$ \\
\hline & CTG & 45 & $10.4 \%$ \\
\hline & Khulna & 41 & $9.4 \%$ \\
\hline & Mymensingh & 19 & $4.4 \%$ \\
\hline & Rajshahi & 48 & $11.1 \%$ \\
\hline & Rangpur & 25 & $5.8 \%$ \\
\hline & Sylhet & 2 & $.5 \%$ \\
\hline & Barisal & 14 & $3.2 \%$ \\
\hline
\end{tabular}

Table 2. The highest percentage of students was doing online classes from Dhaka division $(55.3 \%)$.

\subsection{Knowledge and Attitudes Regarding COVID-19}

Table 3 Knowledge and attitudes regarding COVID-19

\begin{tabular}{|c|c|c|c|}
\hline Characteristics & Variables & $\begin{array}{c}\text { Frequency } \\
\text { (n) }\end{array}$ & $\begin{array}{c}\text { Percentage } \\
\text { (\%) }\end{array}$ \\
\hline \multirow{2}{*}{ When did you get to know about this Covid-19? } & Jan-20 & 208 & $47.9 \%$ \\
\cline { 2 - 4 } & Feb-20 & 116 & $26.7 \%$ \\
\cline { 2 - 4 } & Mar-20 & 110 & $25.3 \%$ \\
\hline From which source you get to know about Covid-19? & Newspaper & 32 & $7.4 \%$ \\
\cline { 2 - 4 } & Television & 88 & $20.3 \%$ \\
\cline { 2 - 4 } & Social Media & 303 & $69.8 \%$ \\
\cline { 2 - 4 } & Personal & 11 & $2.5 \%$ \\
\hline \multirow{2}{*}{ In which place you are living during lockdown? } & Contact & & $89.6 \%$ \\
\cline { 2 - 4 } & Relative home & 7 & $1.6 \%$ \\
\cline { 2 - 4 } & Mess & 5 & $1.2 \%$ \\
\cline { 2 - 4 } & Hostel & 1 & $.2 \%$ \\
\cline { 2 - 4 } & Rented house & 32 & $7.4 \%$ \\
\hline If you are not staying at home, what difficulties are you facing & Food & 42 & $9.7 \%$ \\
\cline { 2 - 4 } during lockdown? & Health & 110 & $25.3 \%$ \\
\cline { 2 - 4 } & Financial & 282 & $65.0 \%$ \\
\hline
\end{tabular}

Table 3 displays the knowledge and attitudes of students during Covid-19. Of 434 respondents, 208 students (47.9\%) got to know about this virus COVID 19 in the month of January 2020, more than two third students $(69.8 \%)$ acquired knowledge or information about this deadly virus COVID 19 from social media which indicates the awareness of various. The highest number of students (89.6\%) stated that during the lockdown situation they were at their own home. It is clearly visible that during this lockdown the students who only stayed their own home were facing huge problems related to financial (65\%) then $25.3 \%$ students faced health problems as well. 
Khadiza Rahman Tanchi, Md Kamruzzaman, Farhana Noor, Shah-Noor Rahman and Gouranga Chandra Debnath

\subsection{Learning Status and Academic Sphere During the Lockdown}

Table 4 Learning status and academic sphere during the lockdown.

\begin{tabular}{|c|c|c|c|}
\hline Characteristics & Variables & Frequency (n) & Percentage (\%) \\
\hline \multirow{3}{*}{ Method of learning during COVID } & Both online and textbook & 147 & $33.9 \%$ \\
\cline { 2 - 4 } & Online studying & 278 & $64.1 \%$ \\
\cline { 2 - 4 } & Reading textbook with own & 9 & $2.1 \%$ \\
\hline \multirow{3}{*}{ Syllabus Covered } & Less than 50\% & 97 & $22.4 \%$ \\
\cline { 2 - 4 } & $50 \%-80 \%$ & 216 & $49.8 \%$ \\
\cline { 2 - 4 } & More than $80 \%$ & 59 & $13.6 \%$ \\
\cline { 2 - 4 } & Final Exam completed & 29 & $6.7 \%$ \\
\cline { 2 - 4 } $\begin{array}{c}\text { How much time do you spend in study } \\
\text { during lockdown? }\end{array}$ & Just started semester & 33 & $7.6 \%$ \\
\cline { 2 - 4 } & Less than normal time spending & 239 & $55.1 \%$ \\
\cline { 2 - 4 } & More than a normal time & 97 & $22.4 \%$ \\
\cline { 2 - 4 } & spending & & \\
\cline { 2 - 4 } & Same as before lockdown & 98 & $22.6 \%$ \\
\hline \multirow{2}{*}{$\begin{array}{c}\text { Do you have any separate reading room } \\
\text { for study? }\end{array}$} & Yes & 261 & $60.1 \%$ \\
\cline { 2 - 4 } & No & 173 & $39.9 \%$ \\
\hline
\end{tabular}

Quite a few questions were asked to find out the overall learning statues and academic spheres of students during this lockdown which includes methods of learning, syllabus covered, and time spending for study with the information of spate reading room at home (Table 4). During the lockdown situation majority of the students were continuing their learning with the method of online studying (64.1\%), whereas second highest number of students $(33.9 \%)$ continue their study with both text book and online study and a very few number of students study through reading textbook with own effort (2.1\%). Quite satisfying result found from the study that despite the lockdown situation $50 \%$ to $80 \%$ syllabus was covered which was ensured by majority of the students (49.8\%). From the study it is found that $55.1 \%$ students which means half of the students mentioned that during this lockdown they spend less time in study compare to normal time. Among 434 students, 261 students (60.1\%) had isolated study rooms for study.

\subsection{Information About Online Classes}

Table 5 Information about online classes.

\begin{tabular}{|c|c|c|c|}
\hline Characteristics & Variables & $\begin{array}{l}\text { Frequency } \\
\text { (n) }\end{array}$ & $\begin{array}{c}\text { Percentage } \\
(\%)\end{array}$ \\
\hline \multirow{2}{*}{$\begin{array}{c}\text { Have you ever attend online classes before } \\
\text { lockdown situation? }\end{array}$} & Yes & 96 & $22.1 \%$ \\
\hline & No & 338 & $77.9 \%$ \\
\hline \multirow{3}{*}{$\begin{array}{l}\text { How many online classes you have attended } \\
\text { for online classes? }\end{array}$} & Above 3 days per week & 304 & $70.0 \%$ \\
\hline & Below 3 days per week & 73 & $16.8 \%$ \\
\hline & \begin{tabular}{|l|} 
Daily \\
\end{tabular} & 57 & $13.1 \%$ \\
\hline \multirow{3}{*}{$\begin{array}{c}\text { What devices or gadgets you have used for } \\
\text { joining online classes? }\end{array}$} & Android Mobile & 318 & $73.3 \%$ \\
\hline & $\begin{array}{l}\text { Laptop/Desktop } \\
\text { Computers }\end{array}$ & 115 & $26.5 \%$ \\
\hline & $\mathrm{Tab}$ & 1 & $.2 \%$ \\
\hline \multirow{3}{*}{$\begin{array}{c}\text { Ownership of the devices or gadgets for } \\
\text { online classes }\end{array}$} & Own & 401 & $92.4 \%$ \\
\hline & Hired from relatives & 13 & $3.0 \%$ \\
\hline & Hired from neighbors & 7 & $1.6 \%$ \\
\hline
\end{tabular}


The Impact of COVID 19 on Higher Education and Way Forward: The Bangladesh Perspective

\begin{tabular}{|c|c|c|c|}
\hline & Hired from friends & 13 & $3.0 \%$ \\
\hline Individuals conducted online classes at $\begin{array}{c}\text { University Teacher } \\
\text { lockdown }\end{array}$ & 289 & $66.6 \%$ \\
\cline { 2 - 4 } & Home tutor & 119 & $27.4 \%$ \\
\cline { 2 - 4 } & $\begin{array}{c}\text { Through conversation } \\
\text { with friends }\end{array}$ & 26 & $6.0 \%$ \\
\hline
\end{tabular}

A number of questions were asked about the overall information of online classes including experience of online classes, attendance of online classes per week, gadgets used in online classes by students, possession of the gadgets which was used in online classes and individuals who were taking classes at lockdown (Table 5). The majority of the students (77.9\%) reported that they did not attend online classes before lockdown. On the other hand it is found that a large number of students $(70 \%)$ stated that they used to do online classes 3 days or above per week. Of 434 students 318 students (73.3\%) used Android mobile for attending online classes whereas the highest number of students $(92.4 \%)$ admitted that the gadgets that they used for online classes were possessed by them. It is reported by a large number of students $(66.6 \%)$ that university teachers conducted online classes at lockdown.

\subsection{Platforms for Online Classes, Materials Sharing, and Evaluation}

Table 6 shows what platforms were used for online classes, how materials were shared with the students and what platforms were used to evaluate or assess the students during this lockdown situation. The result shows that the highest number of students $(61.3 \%)$ used Google Meet for attending online live classes, followed by Zoon app (13.4\%), Facebook live (11.8\%). Students also used different platforms for material sharing as sometimes they did not attend the live classes due to poor internet connectivity. The report result shows that an equal number of students $(31.8 \%)$ used both their institution's self-developed platform and Google Classroom, students $(22.1 \%)$ were also comfortable to share their material through Facebook messenger. Half of the respondents $(50.2 \%)$ think that the software that students were using for their live classes and sharing their study material in that some specifications needed to be added, modified or changed. On the other hand teachers used many platforms for ensuring better teachinglearning through online classes as well as they also tried to ensure proper evaluation through different platforms like email, WhatsApp group, institutions self-developed platform etc. The respondent mentioned that their evaluation was conducted mostly through email $(34.1 \%)$, followed by the institution's self-developed platform $(31.3 \%)$, WhatsApp group $(22.1 \%)$. Additionally student's opinions were also taken about the continuation of online classes. Most of the respondents $(31.1 \%)$ think that universities and teachers should continue online teaching after withdrawing COVID-19 lockdown, second highest number of respondents $(26.0 \%)$ think that universities and teachers should continue online teaching but in a limited way. A large number of students $(74.2 \%)$ think the Government should assist universities to develop required infrastructures and facilities to run online teaching.

Table 6 Platforms for online classes, materials sharing, and evaluation.

\begin{tabular}{|c|c|c|c|}
\hline \multirow{2}{*}{ Characteristics } & Variables & $\begin{array}{c}\text { Frequency } \\
(\mathbf{n})\end{array}$ & $\begin{array}{c}\text { Percentage } \\
(\mathbf{\%})\end{array}$ \\
\hline Platforms usually used for Live online classes & Google Meet & 266 & $61.3 \%$ \\
\cline { 2 - 4 } & Zoom app & 58 & $13.4 \%$ \\
\cline { 2 - 4 } & YouTube Live & 18 & $4.1 \%$ \\
\cline { 2 - 4 } & Skype & 4 & $.9 \%$ \\
\cline { 2 - 4 } & Facebook live & 51 & $11.8 \%$ \\
\cline { 2 - 4 } & Google Classroom & 27 & $6.2 \%$ \\
\cline { 2 - 4 } & Team Link & 10 & $2.3 \%$ \\
\hline \multirow{2}{*}{ The platforms for educational material Sharing } & Institution's self-developed platform & 138 & $31.8 \%$ \\
\cline { 2 - 4 } & YouTube video upload & 16 & $3.7 \%$ \\
\hline
\end{tabular}


Khadiza Rahman Tanchi, Md Kamruzzaman, Farhana Noor, Shah-Noor Rahman and Gouranga Chandra Debnath

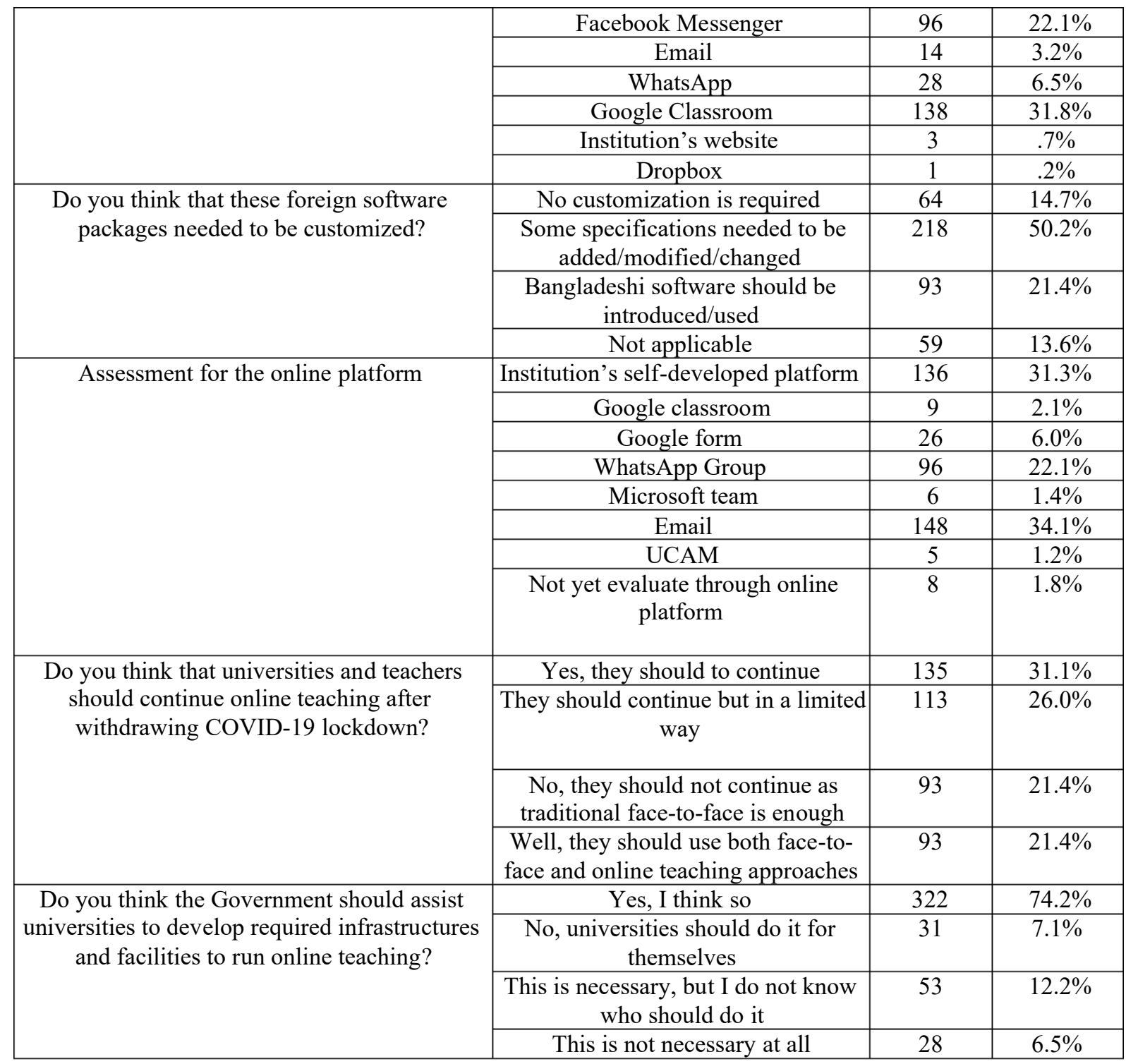

\subsection{Opinion regarding academic decisions and UGC recommendations}

Quite a few questions were asked to the students about their opinion about academic decision and UGC recommendations during this lockdown situation (Table 7). From 434 respondents more than half of the respondents (52.1\%) agreed with the decision of the Bangladesh government for opening the academic institution online after April 14, 2020 which actually indicates that students are concerned about study and their future. Nearly half of the students (42.6\%) agreed about the decisions of examination and academic calendar of the UGC committee whereas $173(39.9 \%)$ students do not know about decisions of examination and academic calendar of the UGC committee. However, 187 respondents (43.1\%) agree with the recommendation of the academic calendar of UGC approved and on the other hand, 183 respondents $(42.2 \%)$ had no idea about the recommendation of UGC's proposed academic calendar. The report also shows that a good number of students (46.1\%) agreed on the examination system, assessment system, and research, field study recommended by UGC whereas 151 students $(34.8 \%)$ were not aware about the system of examination, the evaluation system, research areas and field study recommended by UGC. 
The Impact of COVID 19 on Higher Education and Way Forward: The Bangladesh Perspective

Table 7 Opinion regarding academic decisions and UGC recommendations.

\begin{tabular}{|c|c|c|c|}
\hline Characteristics & Variables & Frequency (n) & Percentage (\%) \\
\hline \multirow{3}{*}{$\begin{array}{c}\text { Do you think Bangladesh government has taken a } \\
\text { good decision about opening academic activities } \\
\text { through online after } 14^{\text {th }} \text { April } 2020 ?\end{array}$} & Yes & 226 & $52.1 \%$ \\
\hline & No & 85 & $19.6 \%$ \\
\hline & $\begin{array}{l}\text { Do not know } \\
\text { about this }\end{array}$ & 123 & $28.3 \%$ \\
\hline \multirow{3}{*}{$\begin{array}{l}\text { Do you agree about the examination and academic } \\
\text { calendar of the UGC committee? }\end{array}$} & Yes & 185 & $42.6 \%$ \\
\hline & No & 76 & $17.5 \%$ \\
\hline & $\begin{array}{l}\text { Do not know } \\
\text { about this }\end{array}$ & 173 & $39.9 \%$ \\
\hline \multirow{3}{*}{$\begin{array}{l}\text { Do you agree with the recommendation of UGC's } \\
\text { proposed academic calendar? }\end{array}$} & Yes & 187 & $43.1 \%$ \\
\hline & No & 64 & $14.7 \%$ \\
\hline & $\begin{array}{l}\text { Do not know } \\
\text { about this }\end{array}$ & 183 & $42.2 \%$ \\
\hline \multirow{3}{*}{$\begin{array}{l}\text { Do you agree on the examination system, assessment } \\
\text { system, and research, field study recommended by } \\
\text { UGC? }\end{array}$} & Yes & 200 & $46.1 \%$ \\
\hline & No & 83 & $19.1 \%$ \\
\hline & $\begin{array}{l}\text { Do not know } \\
\text { about this }\end{array}$ & 151 & $34.8 \%$ \\
\hline
\end{tabular}

\subsection{Impact of COVD-19 on economic condition and educational attendance}

Table 8 Impact of COVD-19 on economic condition and educational attendance.

\begin{tabular}{|c|c|c|c|}
\hline Characteristics & Variables & Frequency (n) & Percentage (\%) \\
\hline \multirow{2}{*}{$\begin{array}{c}\text { Does your family's financial condition has been affected } \\
\text { by covid-19? }\end{array}$} & Yes & 388 & $89.4 \%$ \\
\hline & No & 46 & $10.6 \%$ \\
\hline \multirow[t]{2}{*}{ Does your family's low income affect your education? } & Yes & 369 & $85.0 \%$ \\
\hline & No & 65 & $15.0 \%$ \\
\hline \multirow{3}{*}{$\begin{array}{l}\text { Does covid-19 is the reason of discontinuation of your } \\
\text { study? }\end{array}$} & Yes & 306 & $70.5 \%$ \\
\hline & No & 83 & $19.1 \%$ \\
\hline & Do not know & 45 & $10.4 \%$ \\
\hline
\end{tabular}

Out of 434 respondents, 388 respondents (89.4\%) agreed that the financial condition of their family has already been affected by covid-19 pandemic and another large number of respondents $(85.0 \%)$ also think that their education will be affected by the low income of their family. Additionally quite a good number of students $(70.5 \%)$ also think that they might have to discontinue their education/study due to the covid 19 (Table 8 ).

\subsection{Problems related to study during the lockdown}

The respondents have been asked to rank top five problems/challenges that they face or facing related to study during lockdown. From Table 9, it can be seen that the highest number of students were feeling stress, depressed, and anxious during this lockdown situation. Out of all the alternatives internet connectivity problems has been found to be the second most severe problem faced by the students. At the third place, the problems associated with technical difficulties have been outlined by the respondents. While starting online classes, students feel it is expensive as a huge amount of mobile data has been used during online classes and also after the classes for reading materials as well as considered forth problems or challenges. While studying through online classes, students feel a lack of a favorable environment to study at home is considered a fifth problem. Beyond these problems there were other problems that have been identified by the respondents such as lack of motivation, low income, not having gadgets and digital literacy as well. 
Khadiza Rahman Tanchi, Md Kamruzzaman, Farhana Noor, Shah-Noor Rahman and Gouranga Chandra Debnath

Table 9 Problems related to the study during the lockdown.

\begin{tabular}{|c|c|c|c|c|}
\hline Characteristic & Variables & Frequency (n) & Percentage $(\%)$ & Ranking \\
\hline \multirow{13}{*}{$\begin{array}{l}\text { What kind of } \\
\text { problem/challenges are you } \\
\text { facing or faced related to } \\
\text { study during lockdown? }\end{array}$} & $\begin{array}{l}\text { Feeling of stress, depression, and } \\
\text { anxieties }\end{array}$ & 354 & $81.57 \%$ & 1 \\
\hline & $\begin{array}{l}\text { Problems related to Internet } \\
\text { connectivity }\end{array}$ & 289 & $66.59 \%$ & 2 \\
\hline & $\begin{array}{l}\text { Technical difficulties with online } \\
\text { teaching tools }\end{array}$ & 154 & $35.48 \%$ & 3 \\
\hline & Expensive Mobile data & 153 & $35.25 \%$ & 4 \\
\hline & $\begin{array}{l}\text { Is there have any favorable } \\
\text { environment available at your } \\
\text { home for study }\end{array}$ & 139 & $32.03 \%$ & 5 \\
\hline & $\begin{array}{l}\text { Lack of motivation to join online } \\
\text { learning }\end{array}$ & 111 & $25.58 \%$ & 6 \\
\hline & Low income & 89 & $20.51 \%$ & 7 \\
\hline & Time-consuming resources & 89 & $20.51 \%$ & 8 \\
\hline & $\begin{array}{l}\text { Setting and forgetting online } \\
\text { learning activities }\end{array}$ & 84 & $19.35 \%$ & 9 \\
\hline & $\begin{array}{l}\text { Do not have gadgets for online } \\
\text { study }\end{array}$ & 78 & $17.97 \%$ & 10 \\
\hline & Eye Problem & 65 & $14.98 \%$ & 11 \\
\hline & $\begin{array}{c}\text { Facing problem as I have lack of } \\
\text { Digital Literacy }\end{array}$ & 48 & $11.06 \%$ & 12 \\
\hline & Teachers not interested in teaching & 28 & $6.45 \%$ & 13 \\
\hline
\end{tabular}

\section{CONCLUDING REMARKS}

This pandemic situation of Covid-19 has made substantial interruptions and troubles in academic and regular life activities. The overall educational status of both undergraduate and postgraduate students has been assessed in this present study. Even though a large number of students are using different types of gadgets and technologies for learning purposes, whereas most of the students face huge problems in online study. The present study has suggested some recommendations to the authorities of educational institutions, to the government and policymakers for betterment of students. Initially, educational institutions should offer special waiver for this pandemic situation. All universities should make a uniform academic plan associated with the government to carry out the learning process during this pandemic situation. The government should take initiative to build the infrastructure for digital teaching learning platforms considering future health concerns. The stakeholders of higher education institutions should arrange development training programs as well as ensure sufficient fund management to improve the education system in this pandemic situation. To handle this critical situation, learning management systems and other open learning sources of digital policy should be adopted by the educational institution. As a final point, to keep the young learners and young generation updated and educated the strong education system should be built urgently to develop their skills for a productive and employable candidate for future.

\section{REFERENCES}

[1] Abidah, A., Hidaayatullaah, H. N., Simamora, R. M., Fehabutar, D., \& Mutakinati, L. (2020). The Impact of Covid-19 to Indonesian Education and Its Relation to the Philosophy of "Merdeka Belajar". Studies in Philosophy of Science and Education, 1(1), 38-49.

[2] Favale, T., Soro, F., Trevisan, M., Drago, I., \& Mellia, M. (2020). Campus traffic and e-Learning during COVID-19 pandemic. Computer Networks, 107290. 
The Impact of COVID 19 on Higher Education and Way Forward: The Bangladesh Perspective

[3] Gonzalez, T., de la Rubia, M. A., Hincz, K. P., Comas-Lopez, M., Subirats, L., Fort, S., \& Sacha, G. M. (2020). Influence of COVID-19 confinement on students' performance in higher education. PloS one, 15(10), e0239490.

[4] Kapasia, N., Paul, P., Roy, A., Saha, J., Zaveri, A., Mallick, R., ... \& Chouhan, P. (2020). Impact of lockdown on learning status of undergraduate and postgraduate students during COVID-19 pandemic in West Bengal, India. Children and Youth Services Review, 116, 105194.

[5] Manzoor, A., \& Ramzan, Q. (2020). Online Teaching and Challenges of COVID-19 for Inclusion of Persons with Disabilities in Higher Education.

[6] Pelmin, M. (2020). Readings on Coronavirus Disease (COVID-19) and the Higher Education Institution (HEIs) Emergency Preparedness in the Philippines. Available at SSRN 3573896.

[7] Raju, H. (2020). Covid-19 Lockdown-challenges to higher education, Dr. AIT, ECE Bengaluru,(ongoing project), 20944.

[8] Strielkowski, W. (2020) COVID-19 pandemic and the digital revolution in academia and higher education. Preprints 2020, 2020040290. doi: 10.20944/preprints202004. 0290.v1.

[9] UNESCO. Education: From disruption to recovery. https://en.unesco.org/covid19/ educationresponse/.

[10] WHO Timeline - COVID-19, April 2020, https://www.who.int/news-room/detail/27-04- 2020who-timeline-covid-19. World Health Organisation. 